\title{
5o. Shame by Salman Rushdie from a postmodern frame
}

\section{Neslihan GÜNAYDIN ALBAY 1}

APA: Günaydın Albay, N. (2021). Shame by Salman Rushdie from a postmodern frame. RumeliDE Dil ve Edebiyat Araşttrmaları Dergisi, (23), 797-803. DOI: 10.2900o/rumelide.949697.

\begin{abstract}
Postmodern fiction, which appeared in a post-World War II period, bears distinctive qualities from other literary movements such as realism and modernism structurally, stylistically and thematically. It can be perceived as a challenge against or attack on fixed language systems, subject matters, narrative style, plot development in the face of modernist and realist quest for meaning in a fragmentary world. One of the principal works of postmodern literature published in 1983, Shame by Salman Rushdie exhibits the best features of a post-modern novel by a style of magic realism by touching some political issues and some significant characters in a turbulent Pakistan in the way of historiographic fiction. Although language seems to reflect real historical events, an imaginative and subjective narrative style betrays its break with reality. Shame deserves being called as 'a postmodern novel' in the light of the key characteristics of postmodern fiction such as narrative fragmentation and reflexivity, the decentring of the subject, fictional framing of devices and the plurality of worlds, the displacement of the real by simulacra, magic realism and historiographic metafiction. Therefore, in the novel Shame where the loss of reality and meaning is celebrated rather than lamented, I will try to demonstrate how it is worth the title of "a postmodern novel" by resorting to its comparisons and contrasts with such movements as realism and modernism.
\end{abstract}

Keywords: Salman Rushdie, Shame, postmodern, narrative fragmentation, decentred identity

\section{Postmodern açıdan Salman Rushdie'nin Utanç adlı romanı}

\section{$\ddot{O} \mathbf{z}$}

İkinci Dünya Savaşı sonrası dönemde ortaya çıkan postmodern kurgu, yapısal, üslup ve tematik olarak gerçekçilik ve modernizm gibi diğer edebi akımlardan farklı nitelikler taşır. Parçalanmış bir dünyada modernist ve gerçekçi anlam arayışı karşısında sabit dil sistemlerine, ana fikirlere, anlatı stiline ve olay örgüsüne karşı bir meydan okuma veya saldırı olarak algılanabilir. Postmodern kurguda anlatıcının anlaşılması zor, hayal gücüne dayalı, güvenilmez yorumları ve açıklamaları nedeniyle gerçeklik ile ilüzyon arasında her zaman belirsiz bir sınır vardır. 1983 yılında yayımlanan, postmodern edebiyatın başlıca eserlerinden biri olan Salman Rushdie'nin "Utanç” adlı romanı, tarih yazım kurgu tarzında Pakistan'ın çalkantılı bir dönemindeki bazı siyasi konulara ve bazı önemli karakterlere değinerek post-modern romanın en temel özelliklerini sihirli gerçekçilik üslubuyla sergilemektedir. Başlık, ana tema olarak romana hâkimdir ve çeşitli açılardan sorgulanır. Dil, gerçek tarihsel olayları yansıtıyor gibi görünse de, yaratıcı ve öznel bir anlatı tarzı, gerçeklikle kopuşunu ele verir. Utanç, postmodern kurgudaki kopuk anlatım ve yansıması, öznenin merkezden uzaklaşması, araçların kurgusal çerçevesi ve çoklu ortam, gerçeğin benzerleriyle, sihirli gerçekçilik ve tarih yazımında üst kurgu ile yer değiştirmesi gibi temel özelliklerinden dolayı 'postmodern bir

Dr. Öğr. Üyesi, Doğuş Üniversitesi, İngiliz Dili ve Edebiyatı Bölümü (İstanbul, Türkiye), n.albay87@gmail.com, ORCID ID: 000o-0003-1933-0125 [Araştırma makalesi, Makale kaylt tarihi: 17.12.2020-kabul tarihi: 20.06.2021; DOI: 10.29000/rumelide.949697]

RumeliDE Dil ve Edebiyat Araşttrmaları Dergisi Osmanağa Mahallesi, Mürver Çiçeği Sokak, No:14/8 Kadıköy - ÍSTANBUL / TÜRKIYE 34714 e-posta: editor@rumelide.com tel: +90 $5057958124,+902167730616$
Address

RumeliDE Journal of Language and Literature Studies

Osmanağa Mahallesi, Mürver Çiçeği Sokak, No:14/8

Kadıköy - ISTANBUL / TURKEY 34714

e-mail: editor@rumelide.com,

phone: +90 5057958124 , +90 2167730616 
roman' olarak adlandırılmayı hak etmektedir. Bu nedenle, bu çalışmanın amacı, gerçekçilik ve modernizm gibi akımlarla olan benzerlik ve farklılıklarına da yer vererek, gerçeğin ve mana kaybının ön plana çıkartıldığı Rushdie'nin Utanç adlı romanının, nasıl "postmodern roman” olarak adlandırılabileceğini göstermeye çalışmaktır.

Anahtar kelimeler: Salman Rushdie, Utanç, postmodern, anlatı kopukluğu, bölünmüss kimlik

\section{Introduction}

Postmodern fiction, which appeared in a post-World War II period, bears distinctive qualities from other literary movements such as realism and modernism structurally, stylistically and thematically. It can be perceived as a challenge against or attack on fixed language systems, subject matters, narrative style, plot development in the face of modernist and realist quest for meaning in a fragmentary world. There is always an ambiguous border between reality and illusion because of elusive, imaginative, and unreliable comments and explanations by the narrator in post-modern fiction. Variety in terms of character, places, worlds and subjects is its indispensable feature. The audience bears witness to the formation process of fiction while reading the work itself at the same time and they are exposed to the narrator's deceptive and two-edged role and manner both as a character and as a narrator throughout the novel. Decentred worlds and identities are inescapable for post-modern theory. One of the works of postmodern literature published in 1983, Shame by Salman Rushdie portrays a world stuck between honour and humiliation in an imaginary country. While the novel sheds light on the modernization process of this imaginary country, it self-destructs finally. Throughout the novel Rushdie blends some fantasies and intricacies around characters with the Pakistani reality in order to make an indirect insinuation to the process of modernization in Pakistani history and to the partitioning of the Indian subcontinent.

Shame exhibits the best features of a post-modern novel by a style of magic realism by touching some political issues and some significant characters in a turbulent Pakistan in the way of historiographic fiction. In her book entitled Salman Rushdie: A Postmodern Reading of His Major Works, Sabrina Hassumani notes: "Rushdie attempts to explode the binary categories of cultural classification such as Us/Them, East/West, Self/Other, Margin/Center by deploying postmodern strategies, including deconstruction" (Hassumani, 2002: 20). Kathryn Hume indicates, "Rushdie becomes more concerned with finding active solutions of disinterment" (Hume, 1995: 215). That is, she suggests that, "Rushdie employs his postmodern heroes [...] to demonstrate that a person without a constitutional centre can act in politically productive ways by writing locally, within the community, to achieve specific libertarian and humanitarian ends" (Hume 1995: 219-220). In this analysis of Shame by Rushdie, the writer subverts the monolithic discourse of history through postmodern fiction and metafictional theory. Furthermore, by suggesting "ambivalence is a postmodern keyword" (Kluwick, 2011: 2), Ursula Kluwick regards "Rushdie's magic realism as poised between the postmodern and the postcolonial" and it "can be best understood as the site of a clash between two representational codes" (Kluwick, 2011: 2). The title dominates the novel as the main theme and it is questioned from a variety of perspectives. Although the language seems to reflect real historical events, an imaginative and subjective narrative style betrays its break with reality. Therefore, in the novel Shame where the loss of reality and meaning is celebrated rather than lamented I will try to demonstrate how it is worth the title of "a postmodern novel" by resorting to its comparisons and contrasts with such movements as realism and modernism.

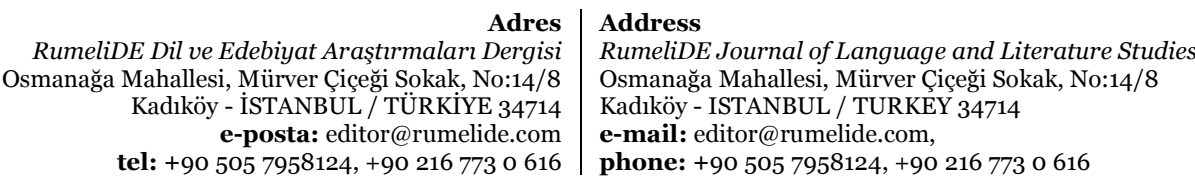


Shame's narrative fragmentation and narrative reflexivity conflict with the traditional plot development of realism and they are celebrated as the features of post-modern novel in opposition to the nostalgic feeling for the loss of reality in modernism. Shame does not have a linear plot development depending on cause-and-effect relation, which refers to breaking down in the realist form in poststructural theory. For instance, in realism, events follow each other successively, but in Shame, we meet a discursive and fragmentary narration. The narrator passes from one subject to another without any connection with each other. The most remarkable feature of postmodern fiction in Shame is that the narrator addresses to the audience directly and makes comments, explanations and criticism on the events. The narrator interferes with the flow of events intrusively. Therefore, there are both first-person and third-person narrators, which adds to the novel an unreliable atmosphere. By referring to postmodern fiction as an "uneasy mix" of history, parody, politics, and metafiction, Linda Hutcheon indicates that this combination

probably historically determined by postmodernism's conflictual response to literary modernism. On the one hand, the postmodern obviously was made possible by the self-referentiality, irony, ambiguity, and parody that characterize much of the art of modernism, as well as by its explorations of language and its challenges to the classic realist system of representation; on the other hand, postmodern fiction has come to contest the modernist ideology of artistic autonomy, individual expression, and the deliberate separation of art from mass culture and everyday life (Hutcheon, 2001: 26).

The subjective unreliable manner of the narrator in Shame drives audience to a world of illusions. The interesting point is that the narrator (or Salman Rushdie) is present in the novel both as a character and as a narrator. He becomes involved in the events he is telling. We bear witness to his writing process of the novel by means of his narrational self-reflexivity and referential frames within frames. On the one hand, he tells events, on the other hand he comments on how he will or should write his novel, which breaks realism. Rushdie creates two Pakistans in the novel, one factual and one fictional existing side by side: "the country in this story is not Pakistan, or not quite. There are two countries, real and fictional, occupying the same space, or almost the same space. My story, my fictional country exist, like myself, at a slight angle to reality. I have found this off-centring to be necessary; but its value is, of course, open to debate. My view is that I am not writing only about Pakistan" (Rushdie, 1983: 2324). Although the narrator asserts that his fictional country does not refer to Pakistan, the parallelisms he draws and his incessant denials demonstrate that he is actually writing about Pakistan and its political life in recent years. For instance, Rushdie stops telling events abruptly and starts to explain the origin of the word "shame" which has a great influence in the lives of characters (Rushdie, 1983: 38). Of course, this fragmentation in Shame exists in every square of the novel including also identity, culture, subjectivity and various lifestyles. Rushdie's narrator hints at fragmentary and perpetually incomplete selfhood when he casually suggests that:

Although I have known Pakistan for a long time, I have never lived there for longer than six months at a stretch ... I have learned Pakistan in slices, the same way as I have learned my growing sister . . . I think what I'm confessing is that, however I choose to write about over-there, I am forced to reflect that world in fragments of broken mirrors ... I must reconcile myself to the inevitability of the missing bits (Rushdie, 1983: 70-71).

The post-colonialist subject is doomed to not only a fragmented history but also a fragmented identity as the migrant. Related to the different viewpoints of modernism and postmodernism on fragmentation, Peter Barry expresses: "for the postmodernists, by contrast, fragmentation is an exhilarating, liberating phenomenon, symptomatic of our escape from the claustrophobic embrace of fixed systems of belief. In a word the modernist laments fragmentation while the postmodernist

\footnotetext{
RumeliDE Dil ve Edebiyat Araşttrmaları Dergisi Osmanağa Mahallesi, Mürver Ciçeği Sokak, No:14/8 Kadıköy - İSTANBUL / TÜRKIYE 34714 e-posta: editor@rumelide.com tel: +90 505 7958124, +90 2167730616 
celebrates it" (Barry, 2002: 84). This is the most remarkable distinctive feature that differs Shame from modern novels. To give an example to the narrational fragmentation and the intrusive and unreliable manner of the narrator in Shame, related to the question "how did three sisters pay for all their expenses after their strange confinement in their mansion" (Rushdie, 1983: 18), the narrator says: "with some embarrassment on their behalf, and purely to show that the present author, who has already been obliged to leave many questions in a state of unanswered ambiguity, is capable of giving clear replies when absolutely necessary, I reveal that Hashmat Bibi [. . .] went to the pawnshop" (Rushdie, 1983: 18-19). At this point, the narrator breaks the narration and reveals background information about events. He accepts that he acts in an ambiguous manner in most places in the novel by using the pronoun "I". We cannot trust the narrator. He plays with us by using different pronouns like "I, you, he". The narrator cannot help infusing his own subjective ideas, comments or directions on readers in a mutual conversation atmosphere besides giving place to the direct speeches of characters by dialogues. The narrator is sarcastic in most parts of the novel and it is not certain whether the speaker is really the narrator or Salman Rushdie. Hence most of the time it is inevitable for readers to be deceived or misdirected by the narrator. Fletcher explains: "unreliable narrators of various kinds and/or multivoiced narrators and other metafictional devices participate in the undermining of absolutes, whether political or religious" (Fletcher, 1994: 16). Similarly, Rushdie's postmodern narrative style breaks with the past and enables readers to question social identification and historical continuity through unreliable narrators.

The narrator in Shame also plays the notion of time in the novel by turning back and forth in time by some flashbacks and different time images. For instance, the narrator explains: "All this happened in the fourteenth century. I am using the Hengiran calendar, naturally: don't imagine that stories of this type always take place long long ago. Time cannot be homogenized as easily as milk, and in those parts, until quite recently, the thirteen-hundreds were still in full swing" (Rushdie, 1983: 13). In this way the narrator emphasizes that time cannot be fixed implying there can happen many twists and turns in different times. Because of the fragmentary structure of the novel, it is remarkably seen that there are many flashbacks, shifts or references to different times, events and subjects in Shame. In his book entitled A Critical Study of the Select Novels of Salman Rushdie, Abhibunnisha Begum notes that "Rushdie uses a sense of timelessness in which the before and after are often reversed. In addition, we cannot always distinguish the exact setting in which he places his characters" (Begum, 2019: 144). The characters recollect and comment on their past memories in their later life and there is not a linear recount of characters and plot development or life stories. The narrator jumps from one subject to another, one person to another, from present to past in age in a few paragraphs. For instance, after the death of old Mr. Shakil three sisters throw a party as a reaction to the news of their ruin. Just after mentioning this, the narrator goes to future and offers a scene from the ironic speeches and comments of three sisters about that notorious gala night in later years. In the same way, we come across an adult Omar Khayyam and his different lifestyle in a relationship with Iskandar Harappa, and then again, there is a return or references to his childhood period and events. There is a circle where all kind of times, subjects and events are put on the agenda frequently and one after the other, which suggests the postmodern structure in Shame. In his book Race, Modernity, Postmodernity: A Look at the History and the Literatures of People of Color since the 196os, W. Lawrence Hogue points out that

Postmodernity engages reflexivity and fragmented authority, questions concepts of subjective consciousness and historical continuity or any totalizing and homogenizing system. Postmodernity interrogates the notion of consensus. It critiques and dispenses with not only positivism ..., but humanism as well, since it calls into question Enlightenment notions of the modern subject (Hogue, 1996: 5).

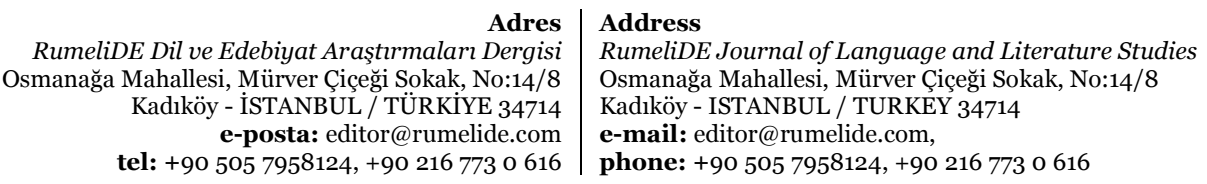


Postmodernism is interrelated with poststructural theory in terms of decentred identity, and decentred universe, instability of meaning and Shame reflects all these features in its nature. One of the main characters of Shame, Omar Khayyam is "born in a death-bed about which there hung the ghost-image of a grandfather who, dying, had consigned himself to the peripheries of hell” (Rushdie, 1983: 21). First, he sees the spectacle of a range of topsy-turvy mountains and he is shaken by a sense of inversion that refers to a world turned upside-down throughout his life. He lives face to face with the feeling that he is living at the edge of the world, so he is under the threat of falling off at any moment. $\mathrm{He}$ is imprisoned in that mansion far from real world and his imagination drives him to thinking he must be near the very Rim of things beyond which the great nothing lies. The narrator questions: "dizzy, peripheral, inverted, infatuated, insomniac, stargazing, fat: what manner of here is this?" (Rushdie, 1983: 25) Omar Khayyam's alienation from real world drives him to a decentred identity and to the feeling of escape from the house in the end. He is brought up by three mothers and with no father in sight. Most things remain a mystery to him. He lives in ignorance for a while, but as he grows up, he is forced to struggle with all things that he is deprived of. Especially his unawareness of "shame" at an early age affects Omar Khayyam deeply throughout his later years, even after he escapes from his mother's zone of influence. While drinking with Iskandar Harappa one day, millionaire playboy, radical thinker, Prime Minister and finally miracle-working corpse, Omar Khayyam says: "you see before you a fellow who is not even the hero of his own life; a man born and raised in the condition of being out of things" (Rushdie, 1983: 24). This dilemma in Khayyam's life dates back to his childhood and maintains its effect in the depth of his soul. He is abstained from many things in early life, so it is inescapable he goes through some shocks when he gets into contact with real life.

The decentring of the subject by discursive systems and the inscription of multiple fictive selves are remarkable postmodern qualities in Shame with the intention to draw attention to the fictional framing devices and the plurality of worlds. In post-modern fiction hybrid identity is seen as a gain as the case in Shame. For instance, Salman Rushdie does not have a precise origin. In an interview, Rushdie states that his problem is one of "multiple rooting":

It's not the traditional identity crisis of not knowing where you come from. The problem is that you come from too many places. The problems are of excess rather than of absence. [...] I've often been asked about my identity crisis and as far as I'm aware I've never had one, never had a feeling of overcrowding. It's not that there are pulls in too many different directions so much as too many voices speaking at the same time (Kaufman, 1983).

Rushdie was born in India, but he lives in England. He experiences inter-cultural interaction. Moreover, the widower old Mr. Shakil raises his children with the help of Parsee wet-nurses, Christian ayahs and an iron mortality that was mostly Muslim. Therefore, children have a very rich cultural background. Stemming from colonialism, two different worlds in Pakistan are also an undeniable fact. The Old town is inhabited by the indigenous, colonized population and Cantt is inhabited by the alien colonizers, the Angrez, or British, sahibs. Moreover, with three sisters named Chunni, Munnee and Bunny the narrator creates multiple fictive selves, which presents audience with an imaginary tale-like world undervaluing reality. They imitate each other and show the same symptoms of birth before Omar Khayyam is born. By means of narrative artifice, it is reflected as if Khayyam were really the son of three mothers in the eye of audience, which is against realism. Creating various fictional or real worlds is celebrated and regarded as gain as characterized in Shame.

One another significant postmodernist quality in Shame is the displacement of the real by simulacra such that the original is always already constructed. In the novel historical fictions are incorporated

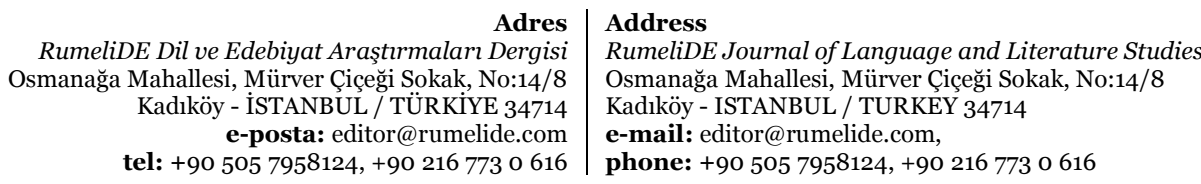


with facts. We cannot decide which one is fact and which one is fiction. History is told like a story. At this point language plays a very important role because it creates an illusionary world in our minds. This narrative style drives us to historiographic metafiction. In Shame, the narrator says: "the country in this story is not Pakistan, or not quite. There are two countries, real and fictional, occupying the same space or almost the same space. My story, my fictional country exists like myself, at a slight angle to reality. I have found this off-centring to be necessary [...] I am not writing only about Pakistan, I have not given the country a name [...] I don't want to be precious about this" (Rushdie, 1983: 29). This explanation of the narrator is the perfect example of postmodernism in Shame. The narrator always plays with reality and fiction, focuses on decenterism, tells the history from a fictional point of view, and gives imaginary names to places, which makes the audience suspicious of whether it is real or fictional. He equates the real with the fictional and he exhibits narrative fragmentation and narrative reflexivity by addressing to audience about the subject of his story. At one point in Shame, the narrator questions the objectivity of historical facts in response to the deception of language and translation. He says: "Is history to be considered the property of the participants solely? In what courts are such claims staked, what boundary commissions map out the territories?” (Rushdie, 1983: 28) by supposing that he took a reaction like "Outsider! Trepasser! You have no right to this subject! Poacher! Pirate! We reject your authority, we know you, with your foreign language wrapped around you like a flag: speaking about us in your forked tongue, what can you tell but lies?" (Rushdie, 1983: 28). This shows that language cannot necessarily reflect facts and it makes us think whether all things told and accepted as facts in history are not inclusive of subjective or fictional additions. Related to the meaning of the word "shame" the narrator prefers using the original form of the word "shame" by claiming Angrezi is "a peculiar language tainted by wrong concepts and the accumulated detritus of its owner's unrepented past, and it so far ever alter what is written" (Rushdie, 1983: 38). He thinks that "shame" is a wholly inadequate translation, since the original word includes a longer context of meaning. Therefore, the role of language in transferring or translating the events or facts is significant, and a little change in meaning can lead to great distortions in the nature of facts. Manipulative aspect of language contributes to magic realism and blinds audience towards reality.

\section{Conclusion}

Shame deserves being called as 'a postmodern novel' in the light of the key characteristics of postmodern fiction such as narrative fragmentation and reflexivity, the decentring of the subject, fictional framing of devices and the plurality of worlds, the displacement of the real by simulacra, magic realism and historiographic metafiction. In no way does the novel inhabit traditional fixed structures and meaning by putting a fragmentary flow of events and distribution of subjects in front of our eyes. By shuttling back and forth between different intervals of time like a time machine, Shame makes time lose its importance and attracts our attention to what happened in various times, places in the lives of different characters discursively. Through various narrative strands such as magicalrealism, unreliable narrators, parody, fairy tales, histories or mimicry Rushdie refers to the serious matters within a postcolonial society and his self-conscious wit enables him to shed light on these problems by way of mockery. Rushdie interweaves shame and violence recurring throughout the novel. As indicated by Hart, Rushdie makes the reader question the cultural norms such as the Orientalist tendencies in the West or the dialectic of shame and violence in the East in order to better understand the absurdities of postcolonial modernity and historical subtleties (Hart, 2008: 20). Deploying postmodernism and magic realism Rushdie paves the way to the suppressed voices rather than the dominant voice refracted by double voices in the postmodern novel Shame. A postmodern device, magic realism enables Salman Rushdie to depict the identity problems of characters facing loss of

\begin{tabular}{r|l} 
Adres & Address \\
RumeliDE Dil ve Edebiyat Arastrmalart Dergisi & RumeliDE
\end{tabular}

Osmanağa Mahallesi, Mürver Çiçeği Sokak, No:14/8 Osmanağa Mahallesi, Mürver Çiçeği Sokak, No:14/8

Kadıköy - İSTANBUL / TÜRKIYE 34714 Kadıköy - ISTANBUL / TURKEY 34714

e-posta: editor@rumelide.com

e-mail: editor@rumelide.com

tel: +90 505 7958124, +90 2167730616 phone: +90 505 7958124, +90 2167730616 
identity. This study analysed the main issues of postmodernism in Salman Rushdie's Shame from the aspects of fragmentation, metafiction and alienation. Furthermore, it demonstrated how Rushdie attempts to recreate and redefine cultural crisis in his imagined homeland from a postmodern perspective with a focus on history, politics and identity crisis based on the consciousness of a "migrant" as seen in his protagonists and his fragmentary selfhood.

\section{Bibliography}

Barry, Peter (2002). Beginning Theory: An Introduction to Literary and Cultural Theory. Second Edition. Manchester and New York: Manchester University Press.

Begum, Abhibunnisha (2019). A Critical Study of the Select Novels of Salman Rushdie. Maharashtra: Laxmi Book Publication.

Dayal, Samir (1998). "The Liminalities of Nation and Gender: Salman Rushdie's "Shame"”. The Journal of the Midwest Modern Language Association, Vol. 31, No. 2, pp. 39-62.

Fletcher, M.D. (1994). Reading Rushdie: Perspectives on the Fiction of Salman Rushdie. Amsterdam. Rodopi, B.V.

Hart, David W (2008). "Making a Mockery of Mimicry: Salman Rushdie's Shame". Postcolonial Text, Vol 4, No. 4 .

Hassumani, Sabrina (2002). Salman Rushdie: A Postmodern Reading of His Major Works, London: Rosemont Publishing.

Hogue, W. Lawrence (1996). Race, Modernity, Postmodernity: A Look at the History and the Literatures of People of Color Since the 1960s, Albany: State University of New York Press.

Hume, Kathyrn (1995). Fantasy and Mimesis: Responses to Reality in Western Literature. New York. Routledge.

Hutcheon, Linda (2001). The Politics of Postmodernism. London and New York: Routledge.

Kaufman, Michael (1983). “Author From 3 Countries.” An Interview with Salman Rushdie. January 22, 2002. The New York Times on the Web. http://www.nytimes.com/books/99/04/18/specials/rushdie_interview83.html.

Kluwick, Ursula (2011). Exploring Magic Realism in Salman Rushdie's Fiction. Routledge.

Rushdie, Salman (1983). Shame. London: Vintage.

Woods, Time (1999). "Postmodernism and Literary Arts". Beginning Postmodernism. Manchester and New York: Manchester University Press, 49-88.

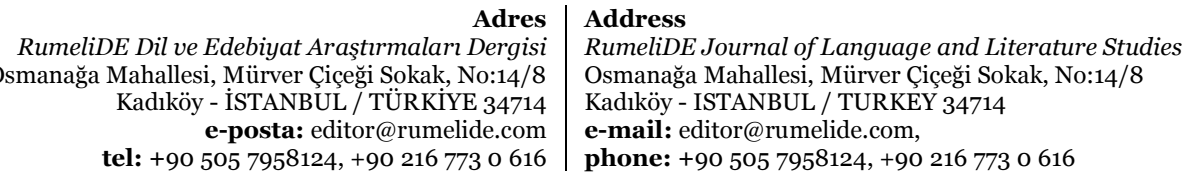

